\title{
Impact of Capital Control on Stock Returns: Evidence from Malaysia
}

\author{
Noel Pavel Nangatie Jeutang \\ University of South Dakota \\ Yewmun Yip \\ University of South Dakota
}

On September 1, 1998, the Malaysian government imposed capital controls in her financial markets, restricting the transfer of funds out of Malaysia. This study examines the impact of the Malaysian government's action on the performance of the 100 stocks that make up the Kuala Lumpur Stock Exchange Index. We find that although there is a negative reaction to the news on the announcement day, the market gains about 70 percent four days later which do not dissipate even after 60 days. We also show that risky and inefficient firms enjoy significant abnormal returns due to capital controls.

\section{INTRODUCTION}

The year following the Asian economic crisis, the Malaysian stock market saw a 60 percent decline in its value, and the Malaysian currency, the ringgit, lost about 40 percent of its value against the U.S. dollar. To prevent further erosion of the value of the ringgit, the Malaysian government had the option to support the ringgit by raising interest rates. However, at the peak of the Asian economic crisis in mid-1998, the Malaysian government was also to trying to find ways to resuscitate its weakened economy. Consequently, raising interest rates was not a viable option.

To counter potential speculative attacks of its currency, on September 1, 1998, the Malaysian government imposed capital controls on her financial markets. This action essentially restricted the transfer of funds out of Malaysia by either Malaysians or foreign investors. The rationale behind the Malaysian government's action was to prevent further depreciation of the Malaysian ringgit. The world was shocked and disbelieved that the Malaysian government would yank itself out of the global economy. This led some analysts to believe that this would mark the beginning of the end of the Malaysian economy.

The reaction to the news was immediate and drastic. The Malaysian stock market lost 13 percent of its value, and the sovereign debt of Malaysia was downgraded by both Moody's and Standard \& Poor. However, the long term effects were not so obvious.

Johnson and Mitton (2003) investigate who benefited the most from the imposition of capital controls by the Malaysian government. They show that firms with strong ties to the Prime Minister, Dr. Mahathir, benefited the most from the implementation of capital controls. They find the value of political connections to be statistically and economically significant, and suggest that capital controls by the Malaysian government protect favored firms. 
In contrast to Johnson and Mitton's 2003 who study the relationship between cronyism and capital controls, we investigate how the Malaysian stock market reacted to the imposition of capital controls. The issues to be investigated are (1) the initial reaction to the news, (2) the long-term effects on the stock market, and (3) the type of firms that benefit the most from the protection provided by capital controls. In other words, beside the well-connected firms, who else will benefit or be hurt by the imposition of capital controls?

Since the economies of Singapore and Malaysia are very closely linked, one would expect the effects of the actions taken by the Malaysian government to spill over into her neighbor's market. Hence, the second issue we examine is the spillover effects of the capital control in Malaysia on the Singaporean economy.

The empirical evidence presented in this paper clearly shows that although the initial reaction to the enforcement of capital controls is negative, capital controls have a positive and statistically significant long-term impact on stock prices after adjusting for the general recovery of the Asian markets. More importantly, the post-event-period price movements in this study seem to support the uncertaininformation hypothesis [Brown, Harlow \& Tinic(1988)] in that investors react cautiously to the government's action. By and large, our results unequivocally indicate that the Malaysian government's intervention is "successful" in supporting and stabilizing the share prices of the 100 companies that make up the Kuala Lumpur Stock Exchange (KLSE) Composite Index.

We also investigate how different segments of the market react to the news. On the event day, large cap firms suffer the largest loss in value. This is perhaps due to a sell off by foreign investors since foreign investors are more likely to invest in large cap firms. The results of regression analysis indicate that after controlling for firm size, inefficient companies with high financial risk tend to benefit the most from the Malaysian government's actions. One plausible explanation is that capital controls act as a shelter for financially weaker companies. Our results concur with the findings of Johnson and Mitton (2003), in that, capital controls tend to foster crony capitalism and protect smaller inefficient companies which may not have survived without such protection.

The paper is organized as follows. The Malaysian government's capital control policy is briefly discussed in Section 2. The data and its sources are summarized in Section 3. Section 4 investigates the direct financial impact of the government's action by applying the event-study methodology to the 100 constituent stocks of the KLSE Composite Index, and also attempts to identify the type of firms that benefited the most from the imposition of capital controls. Finally, Section 5 offers our conclusions.

\section{CAPITAL CONTROLS IMPOSED BY THE MALAYSIAN GOVERNMENT}

The decision by the Central Bank of Thailand to replace its fixed exchange rate system with a managed-floating system in July 2, 1997 triggered a financial crisis in Thailand which eventually spread to other Asian countries such as South Korea, Indonesia and Malaysia. By August 1998, stock markets in these countries including Hong Kong and Singapore saw a drop in their market capitalization of more than 50 percent from their pre-crisis level.

Within a year of the onslaught of the Asian Economic Crisis (from September 1, 1997 to August 13, 1998), the Kuala Lumpur Stock Exchange Composite Index (KLSE), the de facto benchmark for the Malaysian stock market, plummeted by more than 60 percent. The tremendous amount of pressure exerted by speculators on the Malaysian stock market and the Malaysian currency, the ringgit, left the Malaysian government with two choices: 1) impose a currency control while risking retaliation from world capital markets, and/or 2) raise interest rates to support the Malaysian ringgit. However, raising interest rates risked exacerbating the ongoing recession, and hence was not a viable option.

On September 1, 1998, the Malaysian government imposed capital control measures to curb speculative activities, and also to support the Malaysian ringgit. The capital control measures were carefully crafted so as not to hurt foreign manufacturers and other direct investors. One of the measures taken was to peg the Malaysian ringgit to the U.S. dollar at 3.80 ringgits per U.S. dollar. To prevent capital flight, foreign portfolio capital was required to remain in the country for at least a year. In 
addition, the government banned the trading of the ringgit outside the country, thus forcing the repatriation of billions of ringgits. Residents were not allowed to take more than 10,000 ringgit worth of foreign currency out of the country. For overseas investments of more than the equivalent of 10,000 ringgits, prior approval was required before payments could be made to non-residents. Nevertheless, to assure foreign investors, the Malaysian government insisted these measures were only temporary, and once the threat to the Malaysian ringgit disappeared, the capital control measures would be lifted.

The immediate reaction to the enforcements of capital control was very drastic. The Kuala Lumpur Stock Exchange Composite Index, the benchmark for the Malaysian stock market, plunged 13 percent. Moody's downgraded the rating of Malaysia's sovereign debt to just above junk bond status, and Standard \& Poor soon followed suit. A year after the impositions of capital controls, we witnessed a shrinkage of the share of foreign investor holdings of Malaysian shares from almost 30 percent in early 1997 to about 3 percent. In spite of the removal of some of the capital control restrictions, foreign investors continued to be net sellers of Malaysian stocks.

\section{RESEARCH DESIGN}

\section{Data Collection}

Daily returns, $r_{i}$, of the 100 stocks that make up the Kuala Lumpur Stock Exchange (KLSE) Composite Index are obtained from the PACAP Database previously maintained by the University of Rhode Island. The data from PACAP ends in December 31, 1999. To adjust for global market conditions, we use the MSCI World Index from Morgan Stanley Capital International, Inc. as the market index. However, the data is only available from August 29, 1997 resulting in a total of 579 observations for each of the stocks and the MSCI World Index from August 29, 1997 to December 31, 1999. Finally, we collect daily series of the KLSE Composite Index and the Straits Times Index for Singapore from Yahoo Finance! Website.

The previous year's annual financial data for each firm are also obtained from the PACAP database. To ensure that the firm's financial data are available on the event day, we restrict the fiscal year ending date of the financial statements to be at least 3 months before the event date. Since one of the focus of the study is to investigate if firms of different sizes respond differently to the news, firms without market capitalization information are dropped from the sample resulting in a final sample size is 92 .

For comparisons, firms in the final sample are further classified by their market capitalization. Small cap firms are defined as having a market value of less than 250 million ringgits; mid cap firms between 250 million and 750 million ringgits; and large cap firms with a market value greater than 750 million ringgits ${ }^{1}$.

\section{Measuring Abnormal Returns}

To account for the influence of the recovery of the Asian economies, we use an event-study methodology similar to that described in Dodd and Warner (1983) to measure the Malaysian stock market's reaction to the imposition of capital control by the Malaysian government on the event day and during the post-event periods. We define the event day to be the day on which capital control is effective which is September 1, $1998(\mathrm{t}=0)$. We also examine the behavior of stock returns 60 days before the event day from June 5, 1998 to August 28, $1998(\mathrm{t}=-60, \ldots,-1)$ and 60 days after the event period from September 2, 1998 to November 26, $1998(\mathrm{t}=1, \ldots ., 60)$.

An event-study analysis is performed on the 100 stocks that make up the KLSE Composite Index using the single-index market-model's adjusted returns. The parameters of the single-index market model are estimated using the MSCI World Index as the market portfolio over a 186-day period from September 2, 1997 to June 4, $1998(\mathrm{t}=-186, \ldots,-61)$. We then use the parameter estimates to calculate the abnormal returns $\left(A R_{t}\right)$ for the period from June 5, 1998 to November 26, $1998(\mathrm{t}=-60, \ldots, 60)$. The cumulative abnormal return $C A R_{j}(-m,+n)$ for event window from Day $-m$ to Day $+n$ for each stock is then computed. Similar to Brown and Warner (1985), we assume that the abnormal returns, $A R_{j, t}$, and the cumulative abnormal returns, $C A R_{j}(-m,+n)$, are independent for the cross-sectional sample. 


\section{EMPIRICAL RESULTS}

\section{Sample Characteristics}

Table one presents the financial statistics of the following variables from the PACAP database for the firms in the sample:

Market capitalization (in million Malaysian ringgits) is number of shares outstanding times share price as of August 28, 1998.

Beta is computed using the MSCI World Index as the market portfolio.

Price-Earnings Ratio is share price divided by earnings per share.

Market-to-Book Ratio is share price divided by the book value per share.

Profit Margin is net income divided by sales.

Debt Ratio is total liabilities divided by total assets.

Asset Turnover is sales divided by total assets.

Small Cap is defined as firms with market capitalization of less than 250 million ringgits, Mid Cap is for firms with market capitalization between 250 and 750 million ringgits, and Large Cap is for firm with market capitalization greater than 750 million ringgits.

TABLE 1

DESCRIPTIVE STATISTICS FOR THE 100 STOCKS ON THE KUALA LUMPUR STOCK EXCHANGE INDEX

\begin{tabular}{l|cc|cc|cc|c}
\hline \multirow{2}{*}{} & \multicolumn{2}{|c|}{ Small Cap } & \multicolumn{2}{c|}{ Mid Cap } & \multicolumn{2}{c|}{ Large Cap } & F-stat \\
\cline { 2 - 9 } & Mean & SD & Mean & SD & Mean & SD & \\
\hline$N$ & 34 & & 30 & & 28 & & \\
Market Capitalization & 128.76 & 62.60 & 436.30 & 131.12 & $3,126.21$ & $3,376.54$ & $23.10^{* *}$ \\
Beta & 1.33 & 0.57 & 1.32 & 0.67 & 1.29 & 0.72 & 0.03 \\
Price-Earnings Ratio & 7.36 & 9.05 & 8.02 & 18.61 & 110.82 & 511.22 & 0.91 \\
Market-to-Book Ratio & 0.28 & 0.19 & 0.46 & 0.44 & 2.17 & 4.75 & $4.54^{* *}$ \\
Profit Margin & 0.01 & 0.15 & 0.13 & 0.24 & 0.17 & 0.17 & $5.75^{* *}$ \\
Debt Ratio & 0.49 & 0.19 & 0.54 & 0.25 & 0.49 & 0.24 & 0.52 \\
Asset Turnover & 0.47 & 0.27 & 0.45 & 0.35 & 0.70 & 0.64 & $3.04 *$ \\
\hline
\end{tabular}

F-stat tests for equality of means across the three groups $*$ p-value $<0.10$ and $* * p$-value $<0.05$.

As seen in table one, the profit margin, asset turnover and market-to-book ratio of large cap firms are significantly higher than their smaller counterparts. This is perhaps an indication that large cap firms are more efficient and profitable, and as such they command a higher share price relative to their book value suggesting that they may be overvalued. In addition, the large cap firms tend to be more desirable to foreign investors because of their higher liquidity.

\section{Stock Price Response to Imposition of Capital Control}

Table two contains the average cumulative abnormal returns for different event windows. For each of the 100 stocks that make up the Kuala Lumpur Stock Exchange Composite Index, the daily risk-adjusted abnormal returns are estimated using the standard market-model-adjustment whereby the world index by MSCI is used as the market portfolio. The cumulative abnormal return $C A R_{j}(-m,+n)$ for event window from Day $-m$ to Day $+n$ for Stock $j$ is the sum of abnormal returns over the event window. Day 0 corresponds to September 1, 1998, the day on which the Malaysian government imposed a currency control. 
TABLE 2

AVERAGE CUMULATIVE ABNORMAL RETURNS OVER DIFFERENT EVENT WINDOWS

\begin{tabular}{|c|c|c|c|c|c|c|c|c|c|}
\hline \multirow{2}{*}{$\begin{array}{l}\text { Event } \\
\text { Window }\end{array}$} & \multicolumn{2}{|c|}{ All } & \multicolumn{2}{|c|}{ Small Cap } & \multicolumn{2}{|c|}{ Mid Cap } & \multicolumn{2}{|c|}{ Large Cap } & \multirow[t]{2}{*}{ F-Stat } \\
\hline & Mean & t-stat & Mean & t-stat & Mean & t-stat & Mean & t-stat & \\
\hline$N$ & 92 & & 34 & & 30 & & 28 & & \\
\hline Days -3 to 3 & $40.71 \%$ & $15.16^{* *}$ & $49.82 \%$ & $11.99 * *$ & $46.86 \%$ & $9.54 * *$ & $25.57 \%$ & $7.12 * *$ & $10.25 * *$ \\
\hline Days -2 to 2 & $14.97 \%$ & $9.57 * *$ & $19.38 \%$ & $9.48 * *$ & $18.36 \%$ & $6.61 * *$ & $7.00 \%$ & $2.47 * *$ & $7.55 * *$ \\
\hline Days -1 to 1 & $2.50 \%$ & $2.27 * *$ & $6.11 \%$ & $4.19^{* *}$ & $1.46 \%$ & 0.81 & $-0.74 \%$ & -0.32 & $3.76^{* *}$ \\
\hline Days -1 to 0 & $-4.18 \%$ & $-4.10 * *$ & $0.05 \%$ & 0.05 & $-3.35 \%$ & $-2.10 * *$ & $-10.15 \%$ & $-4.83 * *$ & $10.56 * *$ \\
\hline Days 0 & $-3.90 \%$ & $-4.91 * *$ & $-0.61 \%$ & -0.96 & $-2.33 \%$ & $-2.09 * *$ & $-9.58 \%$ & $-5.38 * *$ & $15.21 * *$ \\
\hline Days 0 to 1 & $2.72 \%$ & $3.1 * *$ & $5.49 \%$ & $5.22 * *$ & $2.35 \%$ & $1.80^{*}$ & $-0.17 \%$ & -0.08 & $3.77 * *$ \\
\hline Days -1 to 2 & $12.62 \%$ & $8.41^{* *}$ & $17.25 \%$ & $8.02 * *$ & $13.95 \%$ & $4.97 * *$ & $6.03 \%$ & $2.37 * *$ & $5.71 * *$ \\
\hline Days -1 to 3 & $35.76 \%$ & $13.92 * *$ & $44.46 \%$ & $10.93 * *$ & $39.63 \%$ & $8.10^{* *}$ & $22.18 \%$ & $6.66^{* *}$ & $8.41^{* *}$ \\
\hline Days -2 to 1 & $4.71 \%$ & $4.00 * *$ & $8.24 \%$ & $6.19 * *$ & $5.04 \%$ & $2.53 * *$ & $0.23 \%$ & 0.09 & $4.37 * *$ \\
\hline Days -3 to 1 & $6.84 \%$ & $5.42 * *$ & $10.26 \%$ & $6.90 * *$ & $7.29 \%$ & $3.12 * *$ & $2.64 \%$ & 1.04 & $3.41 * *$ \\
\hline
\end{tabular}

F-stat tests for equality of means across the three groups $*$ p-value $<0.10$ and $* *$ p-value $<0.05$.

Table two shows that on the event day, large cap firms suffer a significant loss of 9.58 percent while mid cap firms lose 2.35 percent and small cap lose 0.61 percent. The loss for small cap firms is statistically not significant perhaps because foreign holdings of these stocks are very miniscule, and hence they are less affected by the withdrawal of foreign portfolio investments. By the same token, large cap stocks experience greater losses probably due to greater exposure to foreign investors. For the event window Days -1 to Days 3, firms of all market capitalization show substantial increase in value with small cap firms gaining the most.

Figure one presents the average $C A R_{t}$ based on the market-model-adjusted returns. For each of the 100 stocks that make up the Kuala Lumpur Stock Exchange Composite Index, the daily risk-adjusted abnormal returns are estimated using the standard market-model-adjustment whereby the world index by MSCI is used as the market portfolio. The cumulative abnormal return, $C A R_{j}(-10, t)$ for day $t$ for each stock is then computed as: $\operatorname{CAR}_{t}(-10, t)=\sum_{k=-10}^{t} A R_{j . k}$. Day 0 corresponds to September 1, 1998, the day on which the Malaysian government imposed a currency control. From Figure one, it seems that investors are reacting cautiously to the enforcement of capital controls as indicated by the gradual rise in value. Four days after the announcement of the restrictions, the market reaches a peak with small cap firms gaining about 70 percent in value. Statistically, the means of the CAR for each size group are different from each other with small cap firms showing the largest gain.

The increase in share value does dissipate. As shown in Figure 1, from Day 6 onwards the average CAR for all size groups stays relatively constant. The long term reaction can be seen in Figure two which shows that the value of the Kuala Lumpur Stock Exchange index continues to rise after September 1, 1998. This is, in part, due to the recovery of the Asian financial markets as similar recovery is also observed for the Singaporean market. 
FIGURE 1

TIME SERIES PLOT OF AVERAGE CUMULATIVE ABNORMAL RETURNS FROM AUGUST 17, 1998 TO SEPTEMBER 15, 1998

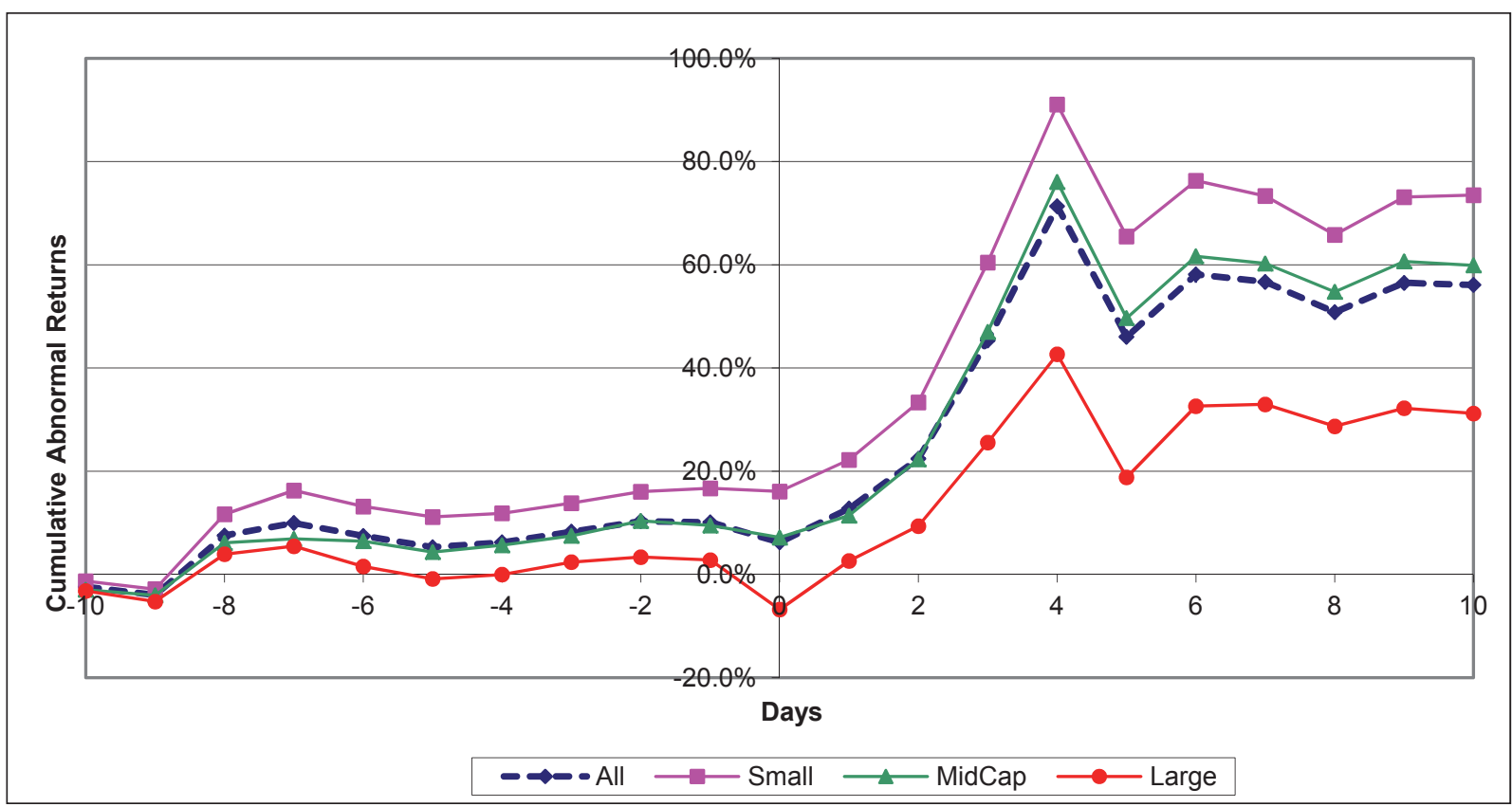

FIGURE 2

TIME-SERIES PLOT OF MARKET INDICES - WI, STI AND KLSE FROM SEPTEMBER 2, 1997 TO DECEMBER 31, 1999

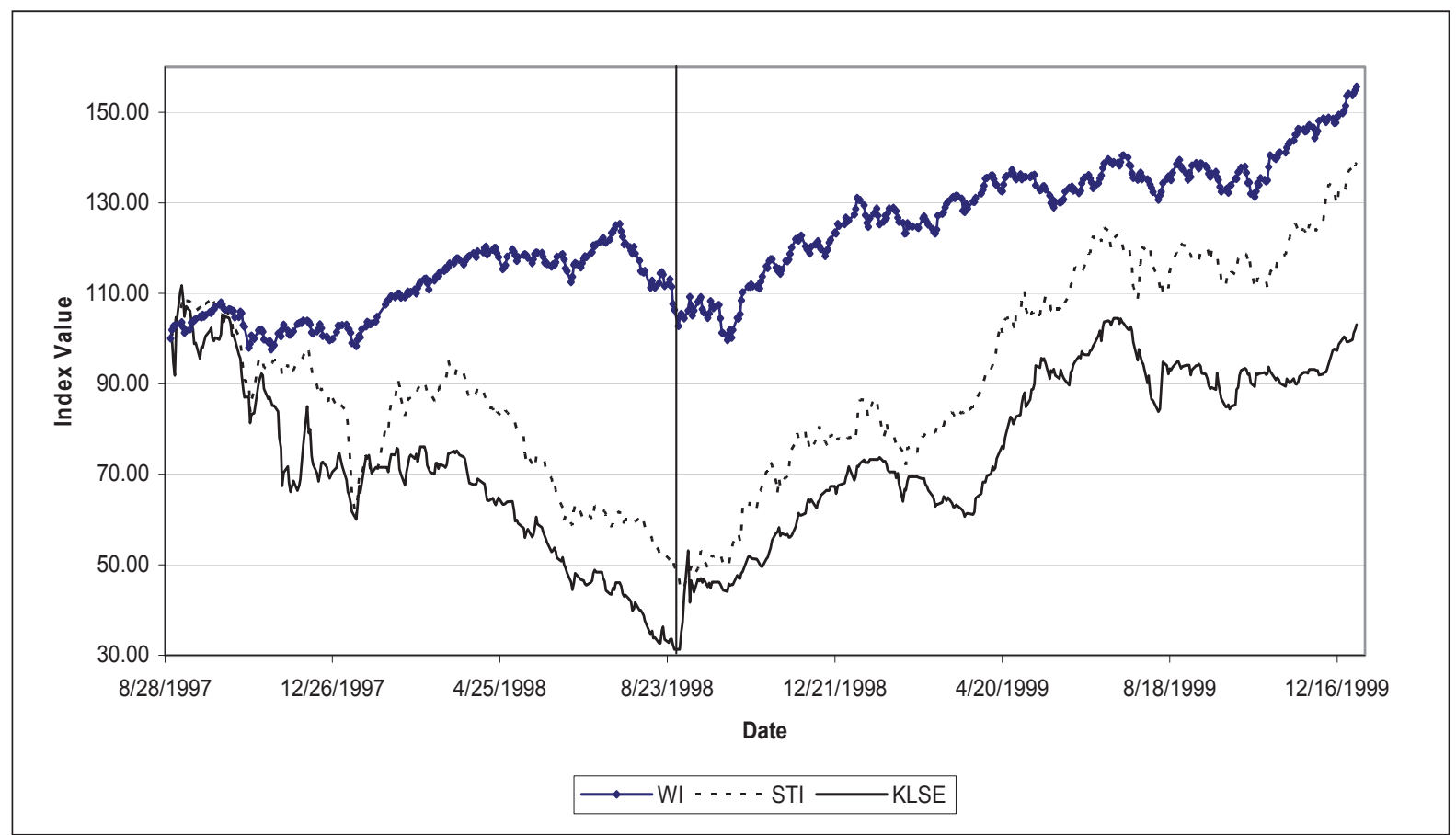


In figure two, WI, STI, and KLSE represent MSCI World Index, Straits Times Index (Singapore), and Kuala Lumpur Stock Exchange Composite Index, respectively. All indices are rescaled to 100 on September 2, 1997. The vertical line marks the day on which capital controls were imposed by the Malaysian government.

In summary, our results clearly indicate that the Malaysian government's imposition of capital controls effectively reversed the declining trend of the 100 stocks that make up the KLSE Composite Index. Except for the event day when the market reacts negatively to news, the positive impact of the government's action remains statistically significant after adjusting for general market movements. The positive permanent price change during the post-event period indicates that the government's action transmits positive signals to investors. In other words, capital control has a permanent influence on the underlying stocks. This positive post-event drift is directly a result of the government's intervention and is not simply a reflection of general market recovery observed during the post-event period. These findings (i.e., a positive permanent price change in the post-event drift) support the uncertain-information hypothesis.

\section{Cross-Sectional Regression Analyses}

In the previous section, we did not control for different firm characteristics. The differences in the reaction by firms of different market capitalization are perhaps due to other factors such as the profitability (Profit Margin), the financial risk (Debt Ratio) and the efficiency in which companies use their assets (Asset Turnover). In this section, we use these three factors to control for differences in firms' characteristics, and examine if firm size makes a difference in the market's reaction to the announcement of capital controls.

Table three reports the results of the three regression models. To allow for possible leak of information, we use a similar procedure used by previous researchers (Chen, Ho, Ik and Lee 2002; Huang and Walking 1987) by using $C A R(-1,0)$ ), the two-day announcement-period abnormal returns for firms that make up the Kuala Lumpur Stock Exchange Composite Index as the dependent variable. The announcement period abnormal returns are estimated using the standard market model procedure with the parameters estimated for the period of 186 days from September 2, 1997 to June 4, 1998. DSIZE1 equals one if the firm's market capitalization is less than 250 million ringgits, and zero otherwise. DSIZE2 equals one if the firm's market capitalization is greater than 250 million ringgits and less than 750 million ringgits, and zero otherwise. DEBT RATIO is the total debt divided by total assets. PROFIT MARGIN is net income divided by sales. ASSET TURNOVER is sales divided by total assets. The numbers in the parentheses are the t-statistics of the parameter estimates. The number of observations varies across different regression models due to availability of data.

The results in table three show that the dummy variable for small cap firm is statistically significant for the two models in which it is included. This undoubtedly indicates that capital control benefited small cap companies the most, that is, they enjoy an additional 9 percent increase in their market value relative to large cap companies while mid cap companies enjoyed an additional 5.9 percent compared to large cap companies. Asset turnover is negative and statistically significant, and debt ratio is positive and statistically significant. Taken together, the results show that after accounting for size, firms with low efficiency and high financially risk gain more from imposition of capital control. Therefore, capital controls can be interpreted as providing a safe haven for high risk and inefficient firms. These results are consistent with the findings of Johnson and Mitton (2003) on the exacerbation of crony capitalism in Malaysia due to the imposition of capital controls. 
TABLE 3

REGRESSION OF EVET-PERIOD ABNORMAL RETURNS

\begin{tabular}{|c|c|c|c|}
\hline \multirow[b]{2}{*}{$\begin{array}{l}\text { Independent } \\
\text { Variables }\end{array}$} & \multicolumn{3}{|c|}{ Models } \\
\hline & 1 & 2 & 3 \\
\hline INTERCEPT & $\begin{array}{c}-0.106 \\
(-2.956)^{* *}\end{array}$ & $\begin{array}{c}-0.025 \\
(-0.820)\end{array}$ & $\begin{array}{c}-0.102 \\
(-6.119) * *\end{array}$ \\
\hline \multirow{2}{*}{ DSIZE 1} & 0.09 & & 0.102 \\
\hline & $-3.654 * *$ & & $-4.555^{* *}$ \\
\hline \multirow{2}{*}{ DSIZE2 } & 0.059 & & 0.068 \\
\hline & $-2.466 * *$ & & $-2.901 * *$ \\
\hline \multirow{2}{*}{ DEBT RATIO } & 0.072 & 0.052 & \\
\hline & $-1.674^{*}$ & -1.147 & \\
\hline \multirow{2}{*}{ PROFIT MARGIN } & -0.051 & -0.119 & \\
\hline & $(-0.999)$ & $(-2.359) * *$ & \\
\hline \multirow{2}{*}{ ASSET TURNOVER } & -0.036 & -0.059 & \\
\hline & $(-1.665) *$ & $(-2.674) * *$ & \\
\hline$N$ & 88 & 88 & 90 \\
\hline Adjusted $R-S q$ & 0.234 & 0.128 & 0.177 \\
\hline F-Stat & 6.32 & 5.24 & 10.56 \\
\hline
\end{tabular}

\section{CONCLUSION}

Our findings indicate that although the market initially reacts negatively to the imposition of capital controls by the Malaysian government, the market gains significantly during the post event period, reaching a peak four days after enforcement. This gain persists in the long term. Small cap firms are the least affected on the event day perhaps because of their size, foreign investors are not attracted to them and hence the market does not register any significant reaction. In the post-event period, small cap firms also gain the most.

From the analysis of firm characteristics, the results show that firms with high financial risk and low in efficiency tend to gain the most from the Malaysian government's actions. This suggests that capital controls perhaps create a shelter for weaker companies, and the market recognizes and takes advantage of it.

\section{ENDNOTE}

1. The cut-off points are chosen such that the sample size in each of the three groups is roughly the same. 


\section{REFERENCES}

Brown, K. C., Harlow, W. V., \& Tinic, S. M. (1988). Risk Aversion, Uncertain Information, and Market Efficiency. Journal of Financial Economics, 31, 355-385.

Brown, S. J., \& Warner, J. B. (1985). Using Daily Stock Returns: The Case of Event Studies. Journal of Financial Economics, 14, 3-31.

Chen, S-S., Kim, W. H., Kueh, H. I., \& Lee, C-F. (2002). How Does Strategic Competition Affect Firm Values? A Study of New Product Announcements. Financial Management, (Summer), 5-22.

Dodd, P., \& Warner, J. B. (1983). On Corporate Governance: A Study of Proxy Contests. Journal of Financial Economics, 11, 401-438.

Huang, Y-S., \& Walking, R. A. (1987). Target Abnormal Returns Associated with Acquisition Announcements. Journal of Financial Economics, 19, 329-349.

Johnson, S., \& Mitton, T. (2003). Cronyism and Capital Controls: Evidence From Malaysia. Journal of Financial Economics, 67, 351-382. 